\title{
TÜRK HALK NINNILERINNE KADIN DİLİNE AİT METAFORLAR ÜZERİNE BİR DEĞERLENDİRME
}

$\ddot{O} z$

Kadın ve erkeğin kullandığı dil, ait oldukları toplum içinde biçimlenir. Ataerkil toplum yapısında, kadının kendi kullandığı dilin özelliklerinden çok, toplum tarafından kadın için belirlenmiş dilin özelliklerine bakmak gerekir ki bu, çoğu zaman toplumda baskın olan erkek dilinin etkisiyle oluşmuş bir dildir. Sözlü edebiyat ürünleri, bu bağlamda kadın diline ait bilgileri de içerir. Bu sözlü ürünlerden biri de ninnilerdir.

Kadınların, erkeklerle karşılaştırıldığında ev, aile, inanç, konuşkan olma, güzellik, giyim, temizlik gibi konularla birlikte düşünülmeleri ve bunlarla ilgili sözcüklerin onların konuşma dilinde yaygınlığı, annelerin icra ettiği ninnilerde kadına özgü bir dilin varlığını düşündürür. Bu sözlerin niteliği belirlenerek kadın dili ortaya konulabilir.

Genellikle çocukları övmeye yönelik niteklikler taşıyan ninnileri anneler, çocuklarının cinsiyetine göre söylemektedirler. $\mathrm{Bu}$ nedenle, annenin kız çocuğu için kullandığı sözler ile erkek çocukları için kullandıkları farklılaşmaktadır. Kız çocuğu için kullanılan benzetme ve sıfatların çoğu toplumda kızın algılanma biçimine uygun olarak narinlik çağrıştırır. Erkek çocuğu için kullanılanlar ise yine erkeğin algılanışına göre daha çok sertlik ve güç içermektedir. Ayrıca hitap edilenin bebek olması, hem annenin konuşma üslubunu yumuşatmakta hem de kadının dili ataerkil toplum yapısının karakterine uygun olarak erkekten daha duygusal ve daha coşkulu bir hâl almaktadır. Kadının açıkça ifade etmediği / edemediği duygular metaforlarla, benzetmelerle ninnilerde yer alır. $\mathrm{Bu}$ nedenle ninnilerde metonomik ve metaforik ifadeler fazlasıyla göze çarpar. Bu yazıda ninnilerde yer alan metafor, benzetme ve metonimlerin ne şekilde ortaya çıtığı ve taşıdığı anlamların sosyal yapıyla gösterdiği paralellik değerlendirilecektir ${ }^{1}$.

Anahtar Sözcükler: Ninni, metafor, kadın dili, benzetme.

\section{AN EVALUATION ON METAPHORS OF WOMAN LANGUAGE IN TURKISH FOLK LULLABIES}

\begin{abstract}
Languages used by woman and man are formed in the society that they belong to. In patriarchal societies, attributes of the language designated to the woman by the society should be investigated, rather than the language woman actually uses. In addition, woman language is a language often formed under the influence of dominant man language in the society. Oral language products includes knowledge of woman language. One of the oral languages products are lullabies.

Association of issues such as home, family, faith, talkativeness, beauty, clothing and cleaning with woman compared to man, and the presence of words related to these issues in woman language leads to the idea of existence of woman-specific verbal expressions in lullabies song by mothers.
\end{abstract}

*Yrd. Doç. Dr.; Sinop Üniversitesi, Fen Edebiyat Fakültesi, Türk Dili ve Edebiyatı Bölümü, songulcekc@ gmail.com. 
Woman language can be identified by identifying attributes of these verbal expressions.

Expressions for the boy and girl generally praising them indicate that the mother sings lullabies for her son and daughter in parallel with their gender roles. Therefore, words mother used for her daughter differentiates from those used for her son. Most of metaphors and adjectives for the girl evoke delicacy in accordance with the perception of the girl in the society. Those used for the boys are in accordance with their perception again, comprises hardness and strength in meaning. In addition, being a baby to be addressed softens the mother's speaking style, and also, in accordance with the character of patriarchal societies, woman language becomes more emotional and enthusiastic than man language. Women's dosen't or couldn't express her feelings that take place in lullabies as metaphors and similes. Thus methaphoric and metonymic expressions or similes are numerously noticeable in lullabies. In this essay will be evaluated what kind of metaphore and metonymy or similes using in lullabies and their meanings parallelism with the social structure.

Keywords: Lullaby, metaphor, woman language, simile.

\section{Giriş}

Belirli bir toplumsal yapı içerisinde var olan bireyin dili kullanımı, sosyal ve kültürel bilincin yansıması olarak kabul edilmelidir. Bireyin kullandığı dili ait olduğu toplumdan soyutlayarak değerlendirmek, çok katmanlı bir yapının sonucu oluşan bireysel dili yüzeysel olarak ele almak demektir. Kullanılan dil geçmişten geleceğe uzanan düşünsel, dilsel ve anlamsal bir yapıdır.

Mikail Bakhtin'in belirttiğine göre dil, somut yapısal birimlerin bileşkesi değil toplumsal bağlam içinde işlev kazanan bir olgudur. Sözün anlam kazanmasında bireyin belli bir bağlamda konuşması önem kazanır. Anlatanın kim olduğu ve kime anlattığı üzerinde durulmalıdır. Dil, sadece grametik sınıflmalar sistemi değil daha çok ideolojik yetkinliği, dünya görüşünü, somut fikirleri, ideolojik hayatın tümünde yüksek seviyedeki karşılıklı anlaşmayı ortaya koyan bir yapıdır (Bakhtin, 1981: 271).

İnsanın dış dünyayla ve öbür bireylerle ilişkilerini yansıtan ve biçimlendiren, düşünceyle birlikte tüm ruhsal ve toplumsal kişiliğini oluşturan dil başkalarını etkileme yönlendirme, yöneltme aracıdır da. Dil, sadece toplumsal değer inaç ve yaşayışı yansıtmakla kalmaz; aynı zamanda etkin bir yönlendirme ve yaratma aracıdır (Vardar, 2001: 16-17).

Dilin toplumsal işlevleri üzerine yoğunlaşan çalışmalar sonrasında dil ve sosyokültürel yaşam arasındaki bağ, ayrı bir alan olarak incelenir. Dilbilimin içinden çıkarak ayrı bir alan hâline gelen, dilin sosyal ve kültürel bir fenomen olduğuna vurgu yapan ve dil - toplum ilişkisini irdeleyen toplum dilbilimi (sociolinguistics) sosyal bilimlerde yer edinir. Toplum dilbilim; toplum ve dil ilişkisini yaş, sınıf, etnik kimlik, cinsiyet bileşenleri ile mercek altına alarak sosyal yapıya dair veri elde etmeyi hedefler (Güven, 2012: 55-62).

\section{TF̂R}


Sözlü kültür ortamında yaratılıp aktarılan anonim şiir örneklerinden biri olan ninnide dil kullanımı, sosyolingustik açıdan değerlendirmeye tabi tutulabilir. Ninnide kadının kullandığı dil, toplumsal yapıdan ve kültürel değerlerden bağımsız olamaz. Bu nedenle ninnilerde sıklıkla görülen metaforlar, benzetmeler ve metonomilerin niteliği kadının tercih, istek ve değerlerini ortaya koyar niteliktedir ${ }^{2}$. Ninnilerdeki bu tip dilsel ifadelerin yüklendikleri anlamlara ve kültürel dille ilişkisine bakılabilir. Yapılan değerlendirme bir yandan ninnilerin edebî, estetik yönünü ifade ederken bir yandan da söz sanatlarının sağladığı örtük dilin varlığını gündeme getirir.

Metaforlar, benzetme (simile) sanatının farklı ilişkilerinden ortaya çıkan bir edebî sanat olarak değerlendirilir. Benzeyen (tenor) ve benzetilen (vehicle) arasındaki ilişki, daha güçlü tutulan kavramın ön plana çıkarılışıyla kurulur. Buna bağlı olarak dört tip metafordan söz edilebilir:

1. Somutlayıcı Eğretileme (Concretive Metaphor): Soyut bir kavrama somut anlam verilerek oluşturulur. 2. Canlılaşmış Ĕgretileme (Animistic Metaphor): Bir nesneye insan ve hayvana ait nitelikler verilerek kurulur. 3. Insanlaşmış Ĕgretileme (Humanising Metaphor): Varlıklara insana ait özelliklerin verilmesiyle kurulur. 4. Girişik Eğretileme (Synaesthetic Metaphor): Diğer üç eğretilemenin birbiriyle kaynaşmış biçimidir. Varlıklara verilen niteliklerde üç eğretileme iç içe geçmiş biçimdedir (Özünlü, 2001: 49-50).

Ninnilere edebî açıdan bakıldığında, bu metaforik kullanımlardan en sık rastlanılanı somutlayıcı metaforlardır. Soyut kavramların daha net anlatılabilmesi, kadının ninnilerde tercih ettiği bir durumdur. Gerçek dünya ve doğa ile içi içe yaşayışın bir sonucu olarak hemen hemen tüm halk şiiri ürünlerinin ortak bir niteliği, gerçek hayata ait somutlukların çağrışım boyutlarıyla birlikte kullanılmalarıdır. Bu düşüncenin sonucu olarak ninnilerde kız ve erkek çocukları sık sık doğaya ait varlıklarla anlatılırlar.

Eğretilemeler / metaforlar, Lakoff ve Johnson'un belirttiği gibi yalnızca edebî değildirler. Çok daha temel gündelik işlevleri vardır. Yüksek - aşağı, alt - üst ile kurulan eğretilemeler gündelik hayata dairdir (Lakoff ve Jhonson, 2005: 26). Bu yaygın eğretilemeler toplum içinde var olan soyut kavramları somutlaştırma işlevine sahiptir. Yukarı - yüksek, alt aşağı gibi somut eğretilemeler düşünme araçları hâline gelir. Gündelik yaşam içinde kavramsal olarak kullanılırlar. Edebî eğretilemelerden farklı olarak bu tip eğretilemeler dikkat çekmez ve bilinçli bir kod açılımı gerektirmez görünürler. Yarattıkları anlam ile toplumun ortak duygusunun bir parçası hâline gelirler, yani sorgulanmadan kabul görürler. Bu tür bir ortak duygu ile doğal ve nedensiz görünürler (Fiske, 2003: 126-127). Lakoff ve Fiske'nin üzerinde durduğu gibi yönelim metaforları kültürden - sosyal yapıdan ayrı düşünülmemelidir. Gündelik 
hayatla sıkı ilişkide bulunan, metafor olduğu hissedilmeyen ifadeler kültürün yansıtıcısıdırlar. İster edebî ister gündelik hayatı anlatır nitelikte olsun anne, ninnilerde kullandığı metaforlarla aslında kültürde var olan ortak bilinci ortaya koyar.

\section{Ninnilerde Metafor Kullanımı}

Ninnileri kapsayan sınıflamalarda tıpkı "ağıt" gibi "türkü" içerisinde gösterilen ve çoğunklukla "ninni yavrum ninni”" ifadesiyle başlayan ninniler, anaların çocuklarını sakinleştirmek ve uyutmak amacıyla söyledikleri ezgili manzumelerdir. Ninnileri söyleyen kadın ya kalıplaşmış şiir örneklerini kullanır ya da doğaçlama yoluyla ninniler söyler. Serzeniş, övgü, yergi, sevgi gibi birçok duyguyu içeren ninniler, bu özellikleriyle başka türlere de yaklaşırlar. Yergi içerenler bedduaya, övgü ağırlıklı olanlar alkışa, serzenişler genellikle ağıta benzer nitelikler gösterirler (Oğuz vd. 2011: 247). Yapı açısından bakıldığında, anonim ninnilerin daha çok yedi heceli ve mani tipinde olduğu; söyleyeni belli ninnilerin ise sekiz ya da on birli heceden oluştuğu görülür. Ninnilerin dize sayısında kararlılık bulunmaz. İkilik, üçlük, dörtlük yapısı yaygın olmakla birlikte beşten on sekiz dizeye kadar uzayan bentlerden oluşan ninniler de vardır (Kaya, 1999: 344, 346-352). Ninnilerde dilek, sevgi, övgü, ayrılık, gurbet, vaat, yergi, şikayet gibi insana özgü hemen her kavram ya da duygu konu edilebilmektedir. Böylesine geniş bir konu alanı bulunan ninnilerde kadının farklı dilsel kullanımlarına rastlamak mümkündür. Bu kullanımlar sözlü geleneğin edebî, estetik ve kültürel dilini yansıtır. Ninnilerde annenin dili kadına özgü ifadelerle doludur. Bunlar, onun toplumsal cinsiyet rolünü yansıtan metaforlarda (metaphor) ve benzetmelerde (simile) karş11ı bulur. Anne, ait olduğu toplumun beğeni ile yergi ifadelerini, övgülerini, beklentilerini, dileklerini ve isteklerini, kısaca hayata ve kendine dair tüm algısını kendi diliyle biçimlendirerek anlatımına katar.

Nalan Büyükkantarcıoğlu'na göre büyük ölçekli dilsel yapılarda, kimi kez açık kimi kez örtük biçimde, kadın için oluşturulmuş toplumsal eğilimlerin izleri görülebilmektedir. $\mathrm{Bu}$ noktada kadının kullandığı dilden çok toplum tarafından kadın için belirlenmiş dilin özelliğine bakmak gerekir ki bu, çoğu kez toplumda baskın erkek dilinin benimsenmesiyle oluşmuş dildir (Büyükkantarcıŏlu, 2006: 73-74). Dolayısıyla ninnilerin estetik yapısı içinde fark edilmesi gereken kadının kullandığı sembolik dilin anlamıdır. Ninnilerde yer bulan çok sayıda benzetme, metafor ve metonomik kullanım, esasen baskın erkek dilinin belirlediği argümanlar etrafında şekillenir.

Kadın, ninni söylerken kullandığı sembolik dille hem toplumsal değer ve rolleri yeniden üretir hem de edebî bir kadın dilini ortaya koyar. Metaforik anlatımlarla çocukta ilk çağrışımları oluşturur, toplumsal ve kültürel yapıya ait ilk bilgileri çocuğa aktarır. Metaforlarla sözlü 
gelenekte yaşayan ninnilerin hafızada tutulması kolaylaşır. Kadın, ninni yaratma anında hafızasında yer etmiş metaforlardan yararlanır.

Lakoff ve Johnson, metaforların kültürden kültüre çeşitlilik gösterebidiğini fakat onların nedensiz olmadıklarını, öncelikle fiziksel, sosyal ve kültürel deneyimlerimizden türemiş olduklarını düşünmüşler ve temel metafor türlerini; yönelim metaforları (orientational metaphors) ile ontolojik metaforlar olarak açıklamışlardır. Yönelim metaforları, bir kavramı diğerine göre bir yapıya kavuşturmayan, bunun yerine bütün bir kavramlar sistemini diğer bir kavramlar sistemine göre organize eden uzay ve mekan ilişkisine yönelik metaforlardır. Ontolojik metaforlar ise; fiziksel nesneler, maddeler ve özellikle kendi bedenimizle ilgili tecrübeler üzerine kurulu olan metaforlardır. Bunlar olay, hareket, duygu ve düşüncelere varlık ve maddeler olarak bakma tarzlarına temel oluşturur (Lakoff ve Johnson, 2005: 50).

Türk halk ninnileri, hem varlık bilgisiyle ilgili (ontological) metaforları hem de yönelim metaforlarını içermektedir. Annenin ninnisine konu olan bebeğin tasvirinde sıklıkla karşılaşılan metaforlar varlık bilgisiyle ilgilidir. Bu metaforlar çocuğun güzelliği, övgüye değer özellikleri veya doğada bulunan canlı - cansız varlık ve durumların nitelikleri kullanılarak gerçekleştirilir. Ninnilerde en sık rastlanan bu tip metaforik ifadeler; çiçek adları, tatlı yiyecek adları, hayvanlar, doğaya ve göksel varlıklara ait durumlardır.

Deyim aktarması ya da eğretileme olarak Türkçe karşıllğını kullanabileceğimiz metaforların edebî dildeki oluşumu için iki temel adlandırma kullanılmaktadır: Diğer bir kavramsal alanı anlamak için metaforik deyimleri alıp kullanacağımız alan "Kaynak Alan", bu şekilde anlaşılması sağlanan kavramsal alan ise "Hedef Alan" olarak adlandırılmaktadır (Kövecses, 2002: 4). Hedef, üzerinde durulan kavramdır. Kaynak ise hedef ile ilgili çıkarımlarda bulunulan, genellikle daha somut bir kavramdır. Ninnilerdeki metaforik kullanımlar bu ayrım ve adlandırma üzerinden değerlendirilebilir. Aşağıdaki ninnilerde öncelikle metaforik ifadelerin anlamsal değerlendirmesi yapılacak, ardından hedef alan ve kaynak alan belirlenecek, sonrasında ise kullanılan metaforların toplumsal cinsiyet algısıyla ilişkisi belirlenmeye çalışılacaktır.

Dandini dandini danadan

Bir ay doğmuş anadan

Eksik olma aradan

Bağışlasın Yaradan (Kaya, 1999: 373).

$\mathrm{Bu}$ ninnide bebeğin güzelliği aya benzetilerek güzellik, hem somut hâle getirilmiş hem de güçlendirilmiştir. Doğaya ait bir varlığın niteliği insan için kullanılmıştır. Bu somutlaştırma 
yoluyla oluşturulmuş (concretive) bir metafordur. Metaforun kaynak alanı "ay"dır. Bu ifade ile anlaşılması istenen hedef alan ise "bebek"tir.

Ninnilerde bebekler daima en güzel ve en iyi sıfatlarla anlatılır. Aynı zamanda, annenin bebeğin güzelliğini anlatmaya yönelik kullandığı ifadeler, gelenekte yaygın olan hâlleriyle karşımıza çıkar. Bu yaygınlık kadının duygu taşıyan dilinde yeniden biçimlenir. Geleneksel yapıda bebek, "ay, nur tanesi, nur topu, ay yüzlü” gibi 1şık saçan bir varlık olarak nitelenir. Olağanüstülük ve mübalağalı anlatım burada tamamen bebeğe yönelmiş olup halk şiirinde sevgili için kullanılan tasvirlerin yerini almıştır. Öte yandan olağanüstüyü, mübalağayı anlatmaya yatkın olan da daha çok kadın dilidir. Robin Lakoff'un da belirttiği gibi kadının dilinde duygusal sıfatlara ait sözcükler fazlasıyla yer alır. Kadınlar duyguları ifade eden dokunaklı sıfatlar kullanır. Beğeni ve takdir belirten sıfatların çoğu feminendir. Harika, sevimli, tapılası, büyüleyici gibi abartılıdır (Lakoff, 1975: 51).

Konuyla ilgili başka bir ninni örneği;

Uyu gözlerin süzülsün

Kirpiğine inci dizilsin

Alnına hayır yazılsın

Ninni gonca gülüm ninni (Demir, 2011: 174).

$\mathrm{Bu}$ ninnide birkaç metaforu bir arada görmek mümkündür. Aksan'a göre deyim aktarmalarının bir türü, doğayla ilgili ögelerin insan için kullanılmasıyla ortaya çıkar. Her dilde görülen bu aktarmalar arasında hayvan adları, doğadaki nesnelerin niteliklerini yansıtan sıfatlar başta gelir. İnsan için melek, pırlanta, fındıkkurdu sözcüklerinin sert, yumuşak, yırtık, pişkin, ağır, hafif gibi sıfatların kullanılışı bu türden aktarmalara girer (Aksan, 2009: 184). Birinci ninninin dili, annenin bebeğin her durumuna duygu katması, genelinde bakıldığında uykuya dalma durumu "gözlerin süzülmesi" biçiminde ifade edilerek yine doğaya ait bir özellik insana aktarılmaktadır. Başka bir ifadeyle söylemek gerekirse; "süzülmek" kavramı, doğada kendiliğinden gerçekleşen durumlarda "akma" anlamıyla kullanılır. Uykuya geçişle yavaş yavaş kapanan gözler için süzülmek ifadesi kullanılmış olup doğaya özgü bir durumun insanın bir parçası olan göze aktarıldığı görülmektedir. Yine somuylayıcı, ontolojik bir metafor kullanılmıştır. İlk dizede kullanılan metaforda kaynak alan "gözlerin süzülmesi”, hedef alan ise “bebeğin gözlerini kapaması”dır.

İkinci dizede geçen "kirpiğine inci dizilsin" ifadesi de metaforiktir. Kirpik, ipe benzetilmiş; ipe dizilen inci ile bebeğin uyurken gözlerinin durumu ifade edilmiştir. İnci, gözyaşı yerine kullanılmış; ağlayan bebeğin uyuduğunda, göz yaşlarının kirpikler arasında ipe dizilmiş inciye benzetildiği görülür. Bu durumda kaynak alan "kirpik", hedef alan "ip" tir. Yine 
kullanılan ifededen tespit edilen diğer metaforun kaynak alanı "inci", hedef alanı ise "gözyaşı" dir.

Dizede, bebeğin göz yaşları ve kirpikleri ziynet eşyası olan inci metaforu ile anlatılmıştır. Annenin benzetmede tercih ettiği kavramlar kendi yaşamındaki güzellik kavramı ile doğrudan ilişkilidir. Kadının bildiği en yaygın değerli taşlardan biri olan inci, ninnide kolaylıkla karşılık bulmuştur. Cansız bir varlık olan inci, insana ait bir özellik için kullanılmış olup somutlayıcı metafor örneği verilmiştir.

Üçüncü dizede "alnına hayır yazılsın" ifadesinde de alın bir deftere benzetilmektedir. "Hayır yazılsın" ifadesi bebeğin kaderinin, bahtının açık ve hayırlı olması dileğini yansıtmaktadır. Kişinin kaderi önceden bellidir. Kaderinde ne varsa onu yaşadığı düşünülür. $\mathrm{Bu}$, deftere yazılmış değişmez bir yazıya benzetilmiştir. Bu metaforun kaynak alanı "alın", hedef alanı ise kader"dir. Somutlayıcı yönelme metaforu olarak değerlendirilebilir.

Annenin bebeğin hayatına ilişkin en büyük dileği hayırlı olmasıdır. Kaderin insanın hayatını belirlediğini düşünerek çocuğun kaderinin, dolayısıyla da kendi geleceğinin de hayırlı olmasını diler. Annenin yaşadığı hayat içinde en büyük dayanağı çocuğudur. Bu nedenle ataerkil toplum yapısında, özellikle erkek çocuğun anneye bakacağı, refah içinde yaşamasını sağlayacağı düşünülür. Anne bu beklentiyi pek çok ninnide dile getirir. Aşağıdaki bir başka ninni, konuyu destekleyecek niteliktedir:

Ninni desem beni yakar

Beşiğinde güller kokar

Oğlum büyür bana bakar

Ninni yavrum ninni (Çelebioğlu, 1995).

$\mathrm{Bu}$ ninni, ataerkil toplum yapısını ve kadının toplumsal cinsiyet rolünü yansıtması bakımından dikkat çekicidir. Ninnilerde en sık rastlanan anlatım tutumlarından biri, geleceğe yönelik beklentilerdir. Gelecek, ninnilerde daima olumlu bulunan bir kavramdır. Ninnilerde geçen "uyusun da büyüsün" ifadesi geleceği anlatır. Büyüyen çocuk, annenin hayal ve beklentilerini gerçekleştirecektir.

Genel olarak bakıldığında, ninnilerin büyük çoğunluğu gelecek tasarımıyla ilgilidir. Kadın, gelecek kavramını, kültür içinde taşıdığı anlam paralelinde olumlu biçimde yansıtır. Kültürdeki temel değerler, ondaki en temel kavramların metaforik yapısıyla uyumludur. "Gelecek daha iyi olacak" beklentisi, kültürün derinliklerinde kök salmıştır. Bu nedenle yukarı, yüksek, ileri metaforları ile anlatılır. Yüksek - yukarı - ileri gibi ifadeler olumlu kabul edilir ve geleceği anlatır (Lakoff, 2005: 45-48). "Büyümek" ifadesi de bu bağlamda olumlu karşılanan, 
geleceği anlatan bir yönelim metaforudur. Kadın için yaşadığı zorlu hayattan kurtulmanın, rahat ve mutlu olmanın yolu, büyüyecek çocuğun iş, meslek sahibi olup anneyi maddi ve manevi anlamda rahatlatmasidir.

Ninninin son dizesinde, "gonca gülüm” ifadesi metaforik kullanımlardan bir diğerdir. Yine doğaya ait bir unsur, bebeğin güzelliğini somutlayarak övmek üzere kullanılmıştır. Halk dilinde var olan ninnilerde en yaygın olan metafor gül ya da gonca güldür. Kız ve erkek çocuk ayrımı yapmaksızın kullanılan metaforlardandır. Hem bebeğin kokusu hem de fiziksel güzelliği için en uygun çiçek olarak görülür. Kaynak alanı "gonca gül”, hedef alanı ise "bebek”tir.

Ninnide kırmızı gülün yaygın kullanımı, bu rengin inanç bakımından taşıdığı anlamı da düşündürür. Kırmızı, bebekleri beşiğe bağlamak ya da kundağı sarmak için kullanılan ipin rengidir (al bağırtlak). "Al kundak, al eyvan, ala kilime sarmak, al bebek" gibi ninniye ait ifadeler kırmızı rengin çocukları koruduğu inancıyla ilgilidir. Kırmızı renk, ninnilerde en sık rastlanan renktir denebilir. Kaynak alanı "gonca gül", hedef alanı ise "bebek"tir.

Kız ve erkek çocukları için söylenen ninnilerde anne, farklı metaforları tercih etmektedir. Kıza dair benzetme ve sıfatların çoğu toplumda kızın algılanma biçimine uygun olarak narinlik çağrıştırır. Kız, hanım hanımcık ve çiçekler kadar güzeldir. Büyüdüğünde meslek sahibi olmak yerine evle ilgili işleri yapmakta hüner göstermesi beklenir. Aşağıdaki ninnide bunu görmek mümkündür.

“Anasıdır danasıdır

Anasinın sunasidir

Anasının has kızıdır

Babasının elmasıdır.

Edasina edasina

Oturmuşlar odasina

Sıvamış beyaz kolların

Hizmet eder babasına" (Çelebioğlu, 1995: 231).

Kız çocuğu için "suna" ve "elmas" metaforlarının kullanımı, toplumun ona yönelik cinsiyet algısına dair fikir vermektedir. Değerli ve parlak bir taş olan elmasın kız çocuğun fiziksel güzelliğini anlatması, sunanın narinliği dile getirmesi, kız çocuklarının fiziksel güzelliğinin ön plana çıkarılmasına yöneliktir. Ninniyi üreten ve kullanan anne, erkek tarafından belirlenmiş rolleri benimser. Buna göre ideal kızlar ve kadınlar uyumlu, özverili, melek gibi, saf ve temiz olmalıdır. Duygusallık kadınla bütünleşen en önemli niteliktir. 
Erkek çocukları için söylenen ninnilerde kullanılan metaforlar, erkeğin toplumsal cinsiyet rolü ile uyumludur. Bunlar daha çok sertlik, güç içeren ninnilerdir. Erkekler aslan, koç, yiğit gibi sıfatlarla tanımlanmaktadır. Kızlar, erkeklere hizmet etmekle görevlidirler ya da onların çapkınlıklarına konu edilirler.
"Haşarıdır oğlum haşarı
Çıkmasın kızlar dışarı
Oğlum kızları görünce

Aslanımın dudağı yaşarı

Oğlum nen nen nen nen" (Çelebioğlu, 1995: 231).

Bu ninnide, erkeğin çapkınlığı anne tarafından küçük yaştan itibaren benimsenmekte ve desteklenmektedir. Yine ninnide geçen "aslanım" ifadesi, erkeğin hem gücünü anlatan hem de onu yücelten bir metafordur. Ninnide kaynak alan "aslan", hedef alan ise "erkek çocuktur".

Erkeğin ataerkil yapıda öne çıkan yanları fiziksel kuvveti ve başarısıdır. Anne, erkeğin toplumsal cinsiyet rolünü bu kavramlar üzerinden kurar ve ninniye aktarır. Burada seçilen metaforla erkeğin nitelikleri daha güçlü kılınmıştır.

Ninniler, övgünün yanı sıra yerginin de sık rastlandığı bir türdür. Fakat çoğunlukla yerilen bebek değil bebeğin etrafında bulunan kimseler ve durumlardır. Anne, bebeğin zarar görebileceği durumlardan onu korumak üzere dua ve beddua niteliği taşıyan ifadeler kullanır. Şu ninni buna örnektir:

"Ninni ninni nestesi

Gül ireyhan destesi

Mustafa'yı sevmeyen

Olsun döşek hastası" (Kaya, 1999: 357).

Ninnide son iki dize bir nevi annenin bedduasıdır. Ninnide geçen "döşek hastası" bir metafordur. Anne, çocuğunu sever ve sevilmesini ister; aksi durumu kabul etmez. Bu duygu çerçevesinde, karşısındakini düşman görür. Kişinin ölmesini değil iyileşemeyecek şekilde ağır hasta olmasını ister. Bunu da dolaylı biçimde dile getirir. "Döşek hastası" ifadesi, yatalak ya da felç olan kimse için kullanılır. Ölümden daha kötü bir durum olarak görülür. Metaforun kaynak alanı" döşek hastası”, hedef alanı ise "ağır hastalıktır".

Hastalık durumu, "döşeğe bağlı olmak" ifadesi ile somutlaştırılmıştır. Kadının dilinde erkeklerden farklı olarak küfre ve argoya sık rastlanmaz. Kadın, duygu ve düşüncelerini ifade etmek için genellikle örtük ifadeler kullanır. Ninnilerde yergi içeren "gözüne tuzun irisi", "aradan kalkmak", "sıtma olup gezememek", “sesi kırılmak", "mezara girmek", “yüreği 
yerinden düşmek" gibi ifadeler kullanılır. Bunlar, kadının örtük dilini yansıtır. Erkeklere göre daha çok duygu içeren bir dil kullanan kadın, söz konusu ninni olduğunda daha dikkatli olmaktadır. Olabildiğince kibar formlar kullanmaktadır. Argo tabirler ve küfür içeren ifadeler, bir erkek tarafından söylendiğinde olağan karşılanmakta; hatta bazı durumlarda desteklenmektedir. Bu desteğin nedeni; çoğunlukla argo ve küfür kullanımının güç ve otorite ile eş değer tutulması, bu şekilde konuşan bir erkeğin güçlü olduğu izleniminin yaratılmasıdır (Kocaer, 2006: 99). Oysa kadın açısından düşünüldüğünde argo veya küfür kullanımı, kadını küçülten bir durumdur. İktidar ve otorite kavramlarının merkezi değil nesnesi konumunda bulunduğundan, kadının bu tip dil kullanımı hoş karşılanmaz.

Yergi ifade eden ninnilerin kimisi de ailede yer alan bireylere dairdir. Konuyla ilgili şu ninni örnek verilebilir:

"Annesi keklik babası toy

Yalaşık bulaşık halalar

Sürmeli gözlü teyzeler

Samur saçlı dayılar

Koca kafalı amcalar” (Çelebioğlu, 1995: 277).

Ninnide, diğer örneklerde olduğu gibi somutlayıc1, ontolojik metaforlar kullanılmaktadır. Somut ve gerçek olan olan varlıklar ve durumlar soyut olan güzellik ve çirkinlik kavramları için kullanılmıştır. Ninnide geçen "keklik", "toy", "samur saç" kaynak alanı oluşturmakta; anne, baba ve annenin akrabaları ise hedef alanı vermektedir. Benzeri biçimde "yalaşık bulaşık", "koca kafalı" sıfatları kaynak alanı vermekte; hedef alanı ise "babanın akrabaları" karşılamaktadır.

Bu tip ninnilerde anne, kendi akrabalarını öven kocasının akrabalarını yeren bir tutum içindedir. Kimi zaman evlilik hayatında kadın, kocası ya da kocasının ailesiyle uyumsuzluk yaşayabilmektedir. Çünkü evlenen kadın yeni bir aileye dahil olur. Görevi, eşine ve ailesine sayg1 göstermek, onların belirlediği kurallar çerçevesinde yaşamaktır. Bu anlamda kendi ailesi ile yeni aile arasındaki tezata mizahi bir üslupla, benzetmelerle vurgu yaparak yaşadığı olumsuzlukları hafifletmeye çalışır.

Ninnilerde s1k rastlanan temalardan biri gurbettir. Kimi zaman anne, kimi zaman baba, kimi zaman da bebek, ayrılık ve yalnızlık duygularıyla ile birlikte anlatılır. Aşağıdaki ninni, anne için gurbetin anlamını vermektedir:

"Karadağımın eteği

Dört yanı aslan yatağı 
Gurbette de dert ortağ1

Ninni gülüm sana ninni” (Çelebioğlu, 1995: 303).

Gurbet duygusunu kadın açısından yansıtan bir başka ninni:

Göçtüğüm göç de Türkmen'in göçü

Vardığım yer de gavurun içi,

Ana beni niye verdin dünya mal için

Ağla anam ağla gözler süzülsün (Çelebioğlu, 1995: 55).

Ninnide gurbet duygusu, dağ metaforu ile dile getirilmektedir. Dağlar, halk şiirinde doğanın betimlenmesinde yer aldığı gibi sevgiliye kavuşmakta araya aşılması zor engeller çıkarması, ayrılı̆̆a neden olması dolayısıyla da sıkça değinilen konulardandır (Aksan, 2005: 34). Ninnide dağlar, dert ortağı olarak betimlenmektedir. Kaynak alan "dert ortağı olmak", hedef alan ise "dağ"dır. Zorluk ve mücadele, kadının dilinde genel olarak "dağ" kavramıyla özdeşleşmiş görünmektedir. Aynı zamanda metaforların bir çeşidi olan "insanlaşmış eğretileme" (humanising metaphor) kullanılarak insana özgü nitelikler başka bir varlığa, dağa aktarılmıştır.

Kadının dilinde gurbet, katlanılması en zor durumlardan bir olarak görülür. Genç yaşta evlenip uzak yerlere giden kadının ailesine duyduğu güçlü özlem, sıklıkla anonim halk şiirinde karşılık bulur (Aksan, 2005: 47). Kadın, yeni girdiği aileye kendini kabul ettirme çabası içindeyken derdini, yalnızlığını ve özlemini ninnilere aktararak ruhsal gerilimini azaltmaya çalışır. Bu nedenle denebilir ki ninnide dert ortağı olarak görülen, hem şiir geleneğindeki yaygın hâliyle dağlar, hem ninni, hem de ninninin muhattabı olan bebektir. Kadın iç sıkıntılarını bebekle yalnızken daha kolay dillendirmektedir.

Gurbet duygusunu kadın açısından yansıtan bir başka ninni:

Göçtüğüm göç de Türkmen'in göçü

Vardığım yer de gavurun içi,

Ana beni niye verdin dünya mal için

Ağla anam ağla gözler süzülsün (Çelebioğlu, 1995: 55).

Ninnide, obadan bir ovaya göçen gelinin ağıt mahiyetindeki yakarışı dikkat çekmektedir. "Göç" sözcüğü yeni bir aileye girişi karşılamakta olup bu "yeni aile" için "gâvurun içi” ifadesi kullanılmıştır. Bu bakımdan dizede metonomik (ad aktarması) bir kullanım mevcuttur. Ayrıca, üçüncü dizede kullanılan “dünya malı” sözü metaforik olup kaynak alanı; dünya malı, hedef alan ise "varlık, zenginlik" tir. Son dizede "ağla anam ağla gözler süzülsün" dizesi, gelinin anası için bir beddua niteliğinde olup yine metaforiktir. "Gözlerin süzülmesi” yukarıda gösterilen ve bebek için kullanılandan farklı bir anlam taşımaktadır. 
Annnenin pişmanlık duyması ve üzüntüden, ağlamaktan gözlerin kapanması istenmektedir. Metaforun kaynak alanı "gözlerin süzülmesi”, hedef alanı ise "gözlerin kapanması"dır.

Yukarıdaki ninni, kızı rahat etsin, kendisi gibi maddi zorluk yaşamasın diye anası tarafından bir ovalıyla evlendirilen, kaynanasıyla geçinemeyip sonrasında ölen Türkmen kızı "Elif'in Ağıtı"dır. Bir hadiseye bağlı tahkiyevi ninnilerdendir (Çelebioğlu, 1995: 55). Görüldüğü üzere, evlenip başka bir çevrede yaşamaya başlayan kadın için yaşanan manevi sıkıntı, ölüm ile sonuçlanacak kadar yıpratıcıdır. Kadın, ninnilerde bu değişimi çoğunlukla sitem ve beddua ile örülmüş şekilde ninnilere katmaktadır. Dolayısıyla metaforlar ve metonomiler kendiliğinden ortaya çıkmaktadır. Kısacası anne, doğrudan ve sözcüklerin gerçek anlamını kullanarak değil dolaylı, yan ve mecaz anlamlar kullanarak kimi zaman da imalarla duygularını dile getirir.

Ninnilerde, baba ile ilişki genellikle sosyal hayatta karşılaşılan sıkıntılar üzerinden dile getirilmektedir. Babanın gurbette oluşu kadın için olumsuzluk yaratan bir başka durumdur.

İstanbul'un yolları diken

Kör olsun dikeni döken

Zalim gurbet babacığın

Aldı gitti, uyu ninni (Çelebioğlu, 2005: 323).

Yukarıdaki ninnide gurbet kavramı "İstanbul”, “zalim”, “diken”, "kör olsun” sözleriyle dile getirilmektedir. Sayısız ninnide "İstanbul” başlangıç kalıp sözü biçiminde kullanılmakta olup (İstanbul'dan çıktım yayan, İstanbul'un yol buducu, İstanbul'un yolu iki, İstanbul'un erenleri, İstanbul'un minaresi, İstanbul'un kestanesi...) babadan ayrilığ 1 anlatan bir metafor olarak kabul edilebilir. Bu bakımdan, kaynak alan "İstanbul", hedef alan ise "gurbet"tir. Uzaklığın yarattığı zorluk "yolları diken" ifadesiyle, gurbete mecbur eden sosyal hayata ilişkin sıkıntılar "kör olsun dikeni döken" ifadesiyle, gurbetin acımasızlığı "zalim" sözüyle karşılanmaktadır. Bu sözler "İstanbul” metaforunun tamamlayıcısı niteliğindedir.

Babanın özellikle geleneksel yapı içindeki statüsü, ailenin geçimini sağlayabilme merkezinde temellenmektedir. Bu nedenle baba ya da en genel anlamda erkek, otorite simgesi ve koruyucu olup kamusal alanla özdeşleşmiştir. Annenin dilinde erkeğin hane dışında, kendisinin ise hane içinde yaşam alanı kurması içselleşmiş ve desteklenmiş olmakla birlikte babanın uzun süreli yokluğu, kadını manevi anlamda zayıflatmaktadır. Bu nedenle, babanın yokluğu bedduaya varan sözlerle dile getirilmektedir.

Kadın, ninnilerde bebek için hayata dair temel bilgileri ilk andan itibaren ninnileriyle aktarır. Bebek, pasif alıcı olsa da zaman içinde toplumsal yaşamın gereklerini öğrenir. 
Ninnilerde yer alan ögütler bu işlevi yerine getirirken onların metaforik kullanımları da dikkat çekmektedir.

Aşağıdaki ninniler durumu örneklemektedir:

Arap atlar eşkin olur

Akan çaylar coşkun olur

Yerine düşmeyen gelin

Ölmez ama şakın olur (Çelebioğlu, 2005: 49).

Yeri yeri yeriden oğul

Yeri dağı eriden oğul

Ayak nere yürürsen

Yavruların geride (Çelebioğlu, 2005: 52).

Oğlan Yürektir

Altın direktir

Kaldırın saklayın

Bir gün gerektir (Çelebioğlu, 2005: 51).

Ninnilerde geçen "Yerine düşmeyen gelin / Ölmez ama şaşkın olur", "Oğlan yürektir / Altın direktir / Bir gün gerektir" dizeleri, kadın ve erkek için toplum tarafından belirlenen değerlerin öğüt biçiminde ninnilere geçmiş hâlidir. Burada kullanılan dil, metaforiktir. İlk ninnide kaynak alan "Yerine düşmeyen gelin", hedef alan ise "kendine uygun biriyle evlenmeyen kadın" olmalıdır.

Diğer ninnide hem "Ayak nereye yürürsen" dizesiyle metonim (ad aktarması) yapılmış annenin bir parçası olan ayak kullanılarak anne kast edilmiş hem de "yavruların geride" ifadesiyle ayak için kişileştirme yapılmış olup insanlaştırılmış metafor kullanılmıştır. Ninnide “ayak sözcügü̈ "anne”yi karşılamaktadır. Dizelerde vurgulanan gitmek, terk etmek vurgusunun kadın için mümkün olmadığı gerçeği, çocukların daima anne yanında düşünülmesi annenin bulunduğu yerden ayrılamamasının temel nedenleridir. Toplum tarafindan kabul görmüş olan bu değer, "anne nereye giderse gitsin yavruları geridedir” gibi öğüt verici bir havaya bürünmüştür.

Son ninnide ise oğlan için benzetmeler, sıfatlar kullanılmış; erkek çocuk cesaret, güç, ve fayda kavramlarıyla özdeşleştirlmiştir. Bu kavramlar kullanılarak aslında kadın tarafından kabul edilen erkek algısı gelenekte sürdürülme imkânı bulmuştur. Geleneksel toplumun yaşayışına uygun olarak erkekler, fiziksel ve manevi güce sahip bir nevi kahraman gibi çizilmektedirler. Kadının görmek istediği erkek tipi de budur. Bu anlayış, ninnide var olduğu gibi kalıp sözlerle, ögüt mahiyetinde dile getirilmektedir. 


\section{Sonuç}

Buraya kadar ele alınan ninniler, oldukça zengin bir ninni hazinesinin birkaç örneğidir. Sınırlı sayıda ninni verilmiş olsa da özellikle övgü, yergi ve geleceğe dair beklenti, ayrılık, gurbet, ögüt içeren ninnilerden ve bunların metaforik anlatımlarından örnekler seçilmiştir. Daha çok ninniden sayısız metafor örneği çıkarmak mümkündür. Ele alınan ninniler, Türk halk ninnilerinin bir kesiti olarak görülmelidir.

Metaforik açıdan değerlendirdiğimiz ninnilerde, türün kendine has niteliği olarak Kabul edebileceğimiz bir takım özellikler ortaya çıkmıştır. Bunlardan biri, annenin gelecek beklentisini ve isteklerini anlatan ninnilerde yönelim metaforlarının sıklıkla kullanılmasıdır. Gelecek, hem külürel yapıda olumlu karşılanmakta hem de kadın için yaşadığı koşulların daha iyi olacağına dair bir beklentiyi içermektedir. Yönelim metaforlarından biri olan "ileri” kavramı, gelecek algisıyla bütünleşmiş görünmektedir.

Metaforlar, kültürden kültüre çeşitlilik gösterebilen ögeler olup fiziksel, sosyal ve kültürel deneyimlerimizden türemiştir (Yaylagül, 2010: 121). Övgü, yergi, öğüt, ayrılık içeren ninnilerde daha çok ontolojik metaforlar göze çarpmaktadır. Ontolojik metaforlar, çoğunlukla bitki ve cansız varlık dünyasından hayvan dünyasına ulaşan bir genişliğe sahiptir. Üzerinde durulan ninnilerdeki metaforların işleyişi çoğu zaman soyuttan somuta geçişi gösterir. Bitki, cansız varlıklar ya da hayvan dünyasından insan dünyasına geçiş yapılarak somutlamalar gerçekleştirilmiştir. Bu yolla, ninnilerde bir başka nitelik olarak somutlayıcı eğretileme biçimi (concretive metaphor) ön plana çıkmaktadır. Bu tip metaforlar soyut bir kavrama somut özellikler kazandırılarak oluşturulur. $\mathrm{Bu}$ metaforların oluşumunda, kadınların yapısal niteliklerine bağlı olarak bebekler; gonca gül, ay, altın, inci, alın yazısı, kader, elmas, hizmet etmek, suna, aslan, döşek hastası, reyhan destesi, keklik, toy, sürmeli göz, ayrılık, dă̆ gibi sözlerle dile getirilmektedir. Annenin dilinde daha çok güzellik kavramı karşılık bulmakta; bu kavram kıymetli taşlar, çiçekler, hayvanlar üzerinden anlatılmaktadır. Aynı zamanda, olumsuz anlam bildiren ifadeler dolaylı yollardan dile getirilmekte; küfür ya da argoya, kadının kibar formlar kullanması gerektiği kabulüyle yer verilmemektedir. Toplumsal yaşayışa ait değerleri içeren ninnilerde, ifadeler öğüte dönüşmekte daha kesin, net kullanımlar göze çarpmakta; -dır / dir ekinin kullanımı bu tip ninnilerde dikkat çekmektedir. Kullanılan metaforlar, toplumsal cinsiyet rollerine uygun olarak kız ve erkek çocuk için farklı kullanımlar doğurmaktadır.

Ninnilerde öne çıkan diğer bir nitelik, kullanılan eylemlerin istek kipinde oluşudur. Bunun yanı sıra özellikle benzetmelerin, ad aktarmalarının bulunduğu ninnilerde betimleyici ifadeler kullanılmıştır. Ancak her iki kullanım şeklinde de doğrudan değil dolaylı bir anlatım sergilenmektedir. Bu durum, kadının toplumsal cinsiyet kimliği ile doğru orantılıdır. Kadının 
çekinik yapısı ninnilerde kendini hissettirmektedir. Dilek ve istek ifade eden ninniler en sık rastlananlardır (uyusun da büyüsün, alnına hayır yazılsın vb.). Bu ninniler, kadının ataerkil toplum yapısı içindeki beklentilerini, hayallerini ortaya koyar. Her ne kadar ninniler çocuklar için söylenen ürünler olsa da esasen kadının kendi dilini rahatça ortaya koyduğu anonim halk şiiri ürünleridir.

\section{Notlar}

1. Bu yazı, 7.02.2014 tarihinde Roma - Sapienza Üniversitesinde "III. European Conference on Social and Behavioral Science" başlıklı sempozyumda sunulan bildirinin genişletilip makaleye dönüştürülmüş biçimidir.

2. Doğan Aksan'a göre; aktarmalardan dünya dillerinde en yaygın olanı deyim aktarmasıdır. Batı stillerindeki karşı1ığı "metaphore", "metaphor", "metapher"dir. Deyim aktarması (metaphore, eğretileme, istiare), sözcügün dile getirdiği kavramla bir başka kavram arasında çoğu kez benzetme yoluyla ilişki kurarak sözcüğü o kavrama aktarma olayıdır [AKSAN, D. (2009). Her Yönüyle Dil. Ankara: TDK Yayınları]. Metonomi (düz değişmece, ad aktarması, mecaz-1 mürsel) olarak adlandırılan anlam olayı ise, anlatılmak istenen kavram kullanılmadan onunla ilgisi bulunan bir başka kavramla dile getirilmesi yoluyla gerçekleşir [AKSAN, D. (2010). Anlambilim Konuları ve Türkçenin Anlambilimi. Ankara: Engin Yayınevi].

\section{Kaynaklar}

AKSAN, D. (2005). Halk Şiirimizin Gücü. Ankara: Bilgi Yayınevi.

AKSAN, D. (2009). Anlambilim Konuları ve Türkçenin Anlambilimi. Ankara: Engin Yayınları.

AKSAN, D. (2010). Her Yönüyle Dil. Ankara: Türk Dil Kurumu Yayınları.

BAKHTIN, M. (1981). "Discourse in the novel" The Dialogic Imagination. (Translated by EMARSON, C. and HOLQUIST, M.). USA: University of Texsas Press.

BÜYÜKKANTARCIOĞLU, N. (2006). Toplumsal Gerçeklik ve Dil. İstanbul: Multilingual Yayınları.

ÇELEBİOĞLU, A. (1995). Türk Ninniler Hazinesi. İstanbul: Kitabevi Yayınları.

DEMIR, N. ve DEMIR, F. (2011). Türk Ninnileri. Ankara: Saraç Yayınları.

FISKE, J. (2003). Illetişim Çalışmalarına Giriş. (çev. İRVAN, S.). Ankara: Bilim ve Sanat Yayınları.

GÜVEN, A. (2012). Toplumsal Dilbiliminin Kapsam Alan1. Pamukkale Üniversitesi Sosyal Bilimler Enstitüsü Dergisi, 13, 55-62.

KAYA, D. (1999). Anonim Halk Şiiri. Ankara: Akçağ Yayınları.

KOCAER, S. (2006). Argo ve Toplumsal Cinsiyet. Milli Folklor, 71, 97-101.

KÖVECSES, Z. (2010). Metaphor, A Practical Introduction. USA: Oxford University Press. 
LAKOFF, J. ve JHONSON, M. (2005). Metaforlar Hayat-Anlam ve Dil. İstanbul: Paradigma Yayınları.

LAKOFF, R. (1975). Language and The Women's Place. New York: Harper Colposon Books.

OĞUZ, M. Ö. vd. (2011). Türk Halk Edebiyatı El Kitabı. Ankara: Grafiker Yayınları.

ÖZÜNLÜ, Ü. (2001). Edebiyatta Dil Kullanımları. İstanbul: Multilingual Yayınları.

VARDAR, B. (2001). Dilbilimin Temel Kavram ve Illkeleri. İstanbul: Multilingual Yayınları.

YAYLAGÜL, Ö. (2010). Divanu Lugati’t-Türk’te Yer Alan Atasözlerindeki Metaforlar. Millî Folklor, 85, 112-121. 